\title{
I LIKE LIVING HERE. SOCIAL STRATAS ATTACHMENT TO THE HUNGARIAN BIG CITIES
}

\author{
Judit BERKES ${ }^{\text {a }}$ \\ ${ }^{a}$ PhD student Széchenyi István University, Doctoral School for Regional Economic Sciences, 9025 Győr, \\ Egyetem tér 1., berkes.judit@sze.hu
}

Cite this article: Berkes, J. (2016). I Like Living Here. Social Stratas Attachment to the Hungarian Big Cities. Deturope, 8, 2: 8-22

\begin{abstract}
Territorial identity and attachment have raised the awareness of researchers from the beginning, as social processes exert a powerful impact on the functioning and also the competitiveness of territories in certain cases. The investigation of these processes is crucial, while citizens, the local population are able to shape and influence the development path of an area. In the perspective of the analysis, social disparities can be defined on one hand from a horizontal and on the other, a vertical or spatial aspect. For the purposes of the current paper, the author used a population survey database of TÁMOP-4.2.2.A-11/1/KONV-20120069 project entitled „Social conflicts - social well-being and security, competitiveness and social development". The investigation of the social structure of the full sample in light of aggregate economic principal components and two aggregate principal components of trust was followed by the analysis of the spatially distinct microsocial structures.
\end{abstract}

Keywords: social identity, attachment, big cities, trust

\begin{abstract}
A területi identitás, kötődés vizsgálata mindig is ébren tartotta a kutatók figyelmét, hiszen a társadalomban zajló folyamatok erőteljes hatással vannak egy adott térség müködésére, sőt akár a versenyképességére is. Azért is fontos ezeket a folyamatokat vizsgálni, mert maga a helyi lakosság, a lokális népesség képes hatni a térség fejlődési pályájára, és befolyásolni azt. Ha a vizsgálat szemszögét kívánjuk áttekinteni, a társadalmi különbségeket meghatározhatjuk egyrészt egy horizontális, másfelől egy vertikális - avagy területi vonalon. Ehhez a vizsgálathoz a TÁMOP-4.2.2.A-11/1/KONV-2012-0069 azonosító számú, „Társadalmi konfliktusok - társadalmi jól-lét és biztonság, versenyképesség és társadalmi fejlődés" címü projekt egyik lakossági felmérésének adatbázisát használtam fel. Elsőként a teljes mintának a társadalmi struktúráját vizsgáltam aggregált gazdasági, majd két aggregált bizalmi fökomponens tükrében, ezt követően tértem rá a területileg elkülöníthető mikrotársadalmi struktúrák elemzésére.
\end{abstract}

Keywords: társadalmi identitás, kötődés, nagyvárosok, bizalom

\section{INTRODUCTION}

The factors of regional growth and development constitute a major field of investigation of regional sciences. The concepts of territorial development and competitiveness were explored by a number of domestic studies (Tóth, Bodor-Grünhut, Jóna, Lengyel, Rechnitzer-Grosz) 
unveiling these territorial determinants as well as their regional, social and socio-cultural impacts.

The concept of territorial capital emerged in modern regional science around the turn of the milleneum. To date, the content and interpretation of the term has not been clarified and it is lacking a universally accepted definition. Despite the substantial similarities and overlaps between available interpretations, a variety of heterogeneous definitions of its content are available. The novelty of territorial capital is that it analyses the role of material and intangible components of capital in local competitiveness, relying on scientific evidence demonstrating the impact of a combination of visible and invisible elements on the economic value of an area.

Within the framework of theories of territorial capital, „soft” factors capable of considerably enhancing territorial competitiveness will be emphasised. The issue of territorial identity is such a factor, and the current study seeks to shed light on the existence of a positive reciprocal relationship between competitiveness and territorial attachment.

\section{Theoretical Foundations of Territorial Identity}

Studies focusing on territorial identity have enjoyed increased popularity recently. Their significance lies in their direct or indirect relevance for each scientific discipline. Professionals have recognised the interrelatedness of regionalisation and identity in Western Europe since the 1970s. Henceforth, there has been a growing demand for the analysis of the social aspects of spatial processes.

Before addressing the issue of territorial identity and the main subjects of the current analysis, it is necessary, however, to present a brief overview of the historical and theoretical antecendents of the concept and its related aspects.

Albeit Gordon W. Allport did not study the existence of identity explicitly, he is recognised as the founder of identity theory in social psychology. The approach of Allport (1954) was not based on society but the self. His contribution to research on attitudes, stereotypes and prejudices has made him one of the most prominent figures in his field, and he analysed a number of aspects of the social existence of the individual.

The next author in the line is McGarty (1999) whose categorizations established in the process of social cognition provide orientation for individuals in everyday life. 
In terms of their typology, identity theories can be divided into two main categories, theories focusing on the individual and those focusing on the community.

The contribution of Aronson (1987) is also an ineluctable element of the introduction of the subject of the current paper. Aronson distinguished three main types of reactions to social influence from a psychological approach: submission, identification and internalisation. According to him, identification is the process whereby the individual under influence desires to emulate the influencing person. Through this process, the individual begins to adopt the opinions and values of the person he desires to resemble.

The theory of Henri Tajfel (1981) draws on the thesis of Allport, however it examines identity from a social aspect. Tajfel identified and analysed social categories and groups, whereby he established the theory of social identity, which he investigated from the perspective of the boundaries of social groups. This provided the basis for his three-stage CIC model (categorisation, identification, comparison): categorisation (development of categories), identification (identification with the category) and comparison (the positive evaluation of the category on the basis of comparison).

Pataki (1986), a domestic representative of identity theory who laid down its groundwork, defined identity as a form of self-awareness which expresses the position of an individual within the community. He distinguishes several types of identities depending on the nature of the group the individual belongs to.

To date, the definition of the concept of identity has still remained ambiguous, and several experts have polemicized on the subject. The notion of regional or territorial identity - or rather the utilisation of the compound word - has gained momentum in recent years, a phenomenon connected to increased liberty arising from modernisation.

Different scientific disciplines adopt heterogeneous approaches to the study of the concept. In the definition of sociology, for instance, it embodies regional or local social relationships (forming the basis of territorial attachment), for politology it expresses the relationship between national identity, territorial claims, the state and its territories, and history emphasises the significance of the historical roots of territorial linkages and cross-border regions (Palkó, 2011).

In the interpretation of the notion of territorial identity, the present study relies on the conceptualisation of Palkó (2011), for whom territorial identity is an organic part of selfconsciousness. The individual regards himself as a member of a group which is defined by well-defined geographic categories and exceeds his personal network of relationships. Its local, territorial, public legal and political legitimacy is largely determined by the identity of 
the local society; moreover, since local attachment may act as a new development resource, the interests of the community can by no means be disregarded. Therefore, territorial identity cannot be interpreted simply as a type of social identity, but rather as a spatial configuration established upon borders. As it contains two coherent categories - a spatio-geographical and a cultural one - which can be interlinked, it may also contribute to regional scientific research via introducing a new socio-pscychological aspect.

There are several prominent domestic contributions to the field (I. Pálné Kovács, Z. Bugovics., G. D. Nagy, J. Szücs, M. Oláh, A. Böhm), however, the research results of Ilona Pálné Kovács merit special attention due to their outstanding relevance to the analysis undertaken in the present study.

Ilona Pálné Kovács was the first to investigate from a politological approach whether the dominance of governmental or regional interests characterises the relationship between settlements and the central government (Pálné Kovács, 1990:3).

Identity has formed an integral part of the works and standpoints of the author related to community spaces, whose presence or absence is not treated as the unique or fundamental determining factor in the formulation of ideas, opinions and models on social spaces. In her research activities consecrated to supporting regionalisation processes, she did not fail to acknowledge the necessity of taking into account the identity-deficit of these spaces during the definition of the responsibilities and competencies of statistical-development regions. These specific circumstances should be counterbalanced by well-designed regional political marketing according to the proposals of Borello (1992) drawing on Latin American experiences. This essentially implies that regions must be constructed both from a sociological and a political viewpoint, since the objective is to empower areas to exploit their own development potentials (Pálné, 2000:54.). Pálné raised the awareness of a number of domestic researchers ${ }^{1}$ to the significance of territorial identity.

Another prominent figure in the research on regional identity, Zoltán Bugovics, whose investigations are closely related to the analyses undertaken by the author, has provided significant contributions to the study of this field. Based on his analysis of the elite of NorthTransdanubia, Bugovics (2004) hypothesized that the territorial identity of individuals is primarily a function of their personal ties, existential factors and the sense of belonging to a group. Beyond these, attachment to various elements of the natural and artificial environment

\footnotetext{
${ }^{1}$ e.g. László Kákai, Katalin Palkó, Gábor Dániel Nagy, Miklós Oláh
} 
is also an influential factor; by contrast, access to community and cultural facilities is less significant.

This study, drawing on the aforementioned results, will undertake the validation of certain hypotheses which are relevant from the aspect of the research area of the author.

\section{Territorial Identity as a Soft Factor In The Theories Of Territorial Capital}

As of recently, the endogenous approach has become the main focus of the theories of regional growth and development in general. It has become increasingly evident that economic and processes can be evaluated more accurately if their analyses does not rely solely on economic factors. According to a statement of the European Commission, GDP is an effective and widely accepted indicator, however, it is inadequate for the quantification of long-term socio-economic progress. Hence the significance of the concept of territorial capital which enables an in-depth study of the spatial structure of the economy.

The concept of territorial capital was defined and applied by the OECD for the first time in 2001. Albeit this was no more than an initial, experimental conceptualisation, its durability, demonstrated by its current efficient application, is unquestionable (Jóna, 2013). The document distinguishes between three segments of territorial capital: visible elements, invisible relations and intangible factors. In reality, the various segments are indistinguishable, mutually constitutive of each other and their distinct treatment is only a theoretical possibility. The sum of three segments produces territorial capital. OECD emphasises the underlying social and cultural conditions of endogenous development in the conceptualisation of territorial capital, which together contribute to reinforcing competitiveness and regional development (OECD, 2001).

Immaterial assets play an important role in present-day regional science. According to the theory of Lin (2001), the history of capital can be divided into two distinct periods: the periods of classical and neo-capital. Classical capital takes only tangible elements into account, while the concept of neo-capital contains reference to intangible elements as well, such as non-quantifiable corporate assets, knowledge management, information handling, personal relationships. According to the author, neo-capital will become increasingly significant (Tóth, 2010). Bourdieu also argued that a full comprehension of the functioning of our world required the extension of the notion of capital and its interpretation through each of its manifestations (Bourdieu, 2004). Marshall was the first to point out the significance of immaterial capital assets, i.e., the outstanding role of intangible elements ,in the air” 
constituting the economic milieu. Among these factors he mentioned the network of institutions, formal and informal rules, local researchers, the norms and interest enforcement capacity of politicians and producers, the day-to-day habits and practices in the local economy (Jóna, 2013).

Non-material capital assets include socio-cultural, geographic factors external to the economy, which nonetheless have an impact regional economic growth and local production processes. Taking account of these factors enables a more accurate evaluation of regional economic processes. Physical capital is characterised by scarcity, therefore, immaterial assets are likely to gradually replace, supplement and substitute the former in the future. This explains the growing emphasis on invisible components of capital. Invisible capital assets represent the same value as tangible resources since these latter can also be mobilised, accumulated, lost and depreciated. Territorial capital seeks to quantify resources which represent (potential) economic benefits for the region, may contribute to local well-being or are unexploited assets.

Giffinger (2007) compared the notions of competitiveness and territorial capital. Both share the same objectives, i.e. to achieve and sustain regional well-being. However, territorial capital considers invisible assets to be a significant factor of territorial competition, and attributes an important role to the combination of the factor of knowledge/competence and territorial dynamics as well.

In order to be able to contribute to local well-being, immaterial capital assets need to be converted into material assets. Symbolic capital, i.e. assets and capacities of individuals and institutions which enable them to convert available capital assets into other types of capital is an essential condition of their conversion. Sustainability requires an increase of invisible capital in direct proportion with the diminution of physical capital. This necessitates the appropriate utilisation of symbolic by the regional institutional system and members of local society. Immaterial goods may contribute to the economic development of a region provided that they are recognised and utilised by the members of local society and converted into immaterial assets by the means of symbolic capital (Jóna, 2013).

Theories of territorial capital acknowledge the obvious influence of a phenomenon difficult to measure yet manifest in the engine of development of a given area on exact, quantifiable development. The extent to which the presence of local society is a significant factor in a geographically delimited area can by no means be ignored either. 


\section{Attachment To Cities - On the Margin of a Concluded Research}

A large-scale research programme (in partnership with Széchenyi István University) ${ }^{2}$ which facilitated the investigation of the relationship between social conflicts and well-being was concluded at the Kodolányi János College in 2014. In addition to providing a systematic analysis of the theoretical background, the research team analysed the possible types of social conflicts (demographic, private, workplace, neighbourhood) from various perspectives on the basis of a database derived from a national survey, which may provide orientation for the future transformations of the social structure $(\mathrm{N}=5000$, in Hungarian cities and their urban areas: Budapest, Debrecen, Győr, Kecskemét, Miskolc, Nyíregyháza, Pécs, Szeged, Székesfehérvár.

The mentioned database facilitated the evaluation of various hypotheses presented in the theoretical section of the study.

The published volume of studies contains an analysis of various aspects of identity-based attachment to the place of residence based on a different national data survey, however, the current paper seeks only to examine the degree of attachment to cities with a county status.

The main objective of the analysis is to find out whether the inhabitants of economically successful regions and spatial units demonstrate a stronger attachment to their area than those of less developed regions, and if so, what are the forms of its manifestation, can social milieux be typified on these grounds in the urban areas in question.

In the following, we are going to explore the validity of this hypothesis in the context of cities with a county status.

A database adopted from a previous analysis (Rechnitzer J., Páthy Á, Berkes J. 2014) will be used for the review of economic data, in the framework of which a complex multivariate economic indicator was developed. First, individual variables were organised into thematic principal components which contain variables of identical dimension and a high explanatory value. The collection of variables relied on various economic, qualification, human, social activity and innovation data. The principal component scores are standardised indicators used for the classification of the distinguished dimensions. The analysis covered 328 settlements with a city status in 2011 - excluding Budapest - whereas the current paper examines only 9 cities with a population over 100000 inhabitants and their immediate catchment areas.

\footnotetext{
${ }^{2}$ TÁMOP-4.2.2.A-11/1/KONV-2012-0069 project entitled „Social conflicts- social well-being and security, competitiveness and social development".
} 
Based on the developed principal components, scores were attributed to each city, indicating its development level from a specific aspect. Cities' higher development levels are reflected by higher scores.

Table 1 The economic principal component scores of cities with a county status

\begin{tabular}{|c|c|c|c|}
\hline Name of settlement & Scores & $\begin{array}{c}\text { Name of } \\
\text { settlement }\end{array}$ & Scores \\
\hline Székesfehérvár & 2.01 & Sopron & .95 \\
Györ & 1.64 & Tatabánya & .95 \\
Veszprém & 1.62 & Szeged & .84 \\
Szombathely & 1.57 & Nagykanizsa & .81 \\
Szekszárd & 1.35 & Debrecen & .79 \\
Zalaegerszeg & 1.34 & Pécs & .68 \\
Dunaújváros & 1.28 & Kaposvár & .57 \\
Érd & 1.15 & Békéscsaba & .40 \\
Kecskemét & 1.15 & Miskolc & .31 \\
Eger & 1.13 & Hódmezóvásárhely & -.11 \\
Szolnok & .99 & Salgótarján & -.30 \\
Nyíregyháza & .96 & & \\
\hline
\end{tabular}

Source: Own elaboration based on data from the research programme on the Vehicle Industrial District in Györ, 2015

The table demonstrates that the top-ranking cities with a county status from the aspect of economic development are Székesfehérvár, Győr, Veszprém, Szombathely, while the worst indicators were detected in the case of Salgótarján and Hódmezővásárhely.

\section{METHODOLOGY}

The database used for the purposes of the analysis was sufficiently weighted in terms of criteria of representativity (age and qualification) based on relevant data of the 2011 population census. In the initial phase, vertical disparities in the full sample were examined in terms of qualification (four categories were established on the basis of a variable composed of multiple categories: elementary school, secondary school with graduation, secondary school without graduation, tertiary education) and income. In the case of this latter, the aggregate indicator was composed of three variables:

- the number of durables owned by households

- savings, investments - any forms of savings or investments in cash, on a bank account, in a bank deposit, stocks, mutual funds, supplementary pension schemes, life insurance, objects of art, valuables, other 
- the net monthly income of households (adjusted variables were used due to the high rate of non-respondents)

Qualification and income together constitute a single economic principal component, which functions as a control for economic indicators of the previously mentioned research. The principal component proved to be statistically utilisable $(\mathrm{KMO}=0,686)$.

The figure below depicts the average values and deviations (variance) of economic principal components of the investigated cities (their urban area). The larger the space they occupy on a given box, the larger the hypothesized internal disparities will be. The population of Pécs, for instance, is considerably more fragmented than that of Kecskemét. The position of mean values in the figure is also heterogeneous.

Figure 1 Deviations from the mean values of principal components of urban areas

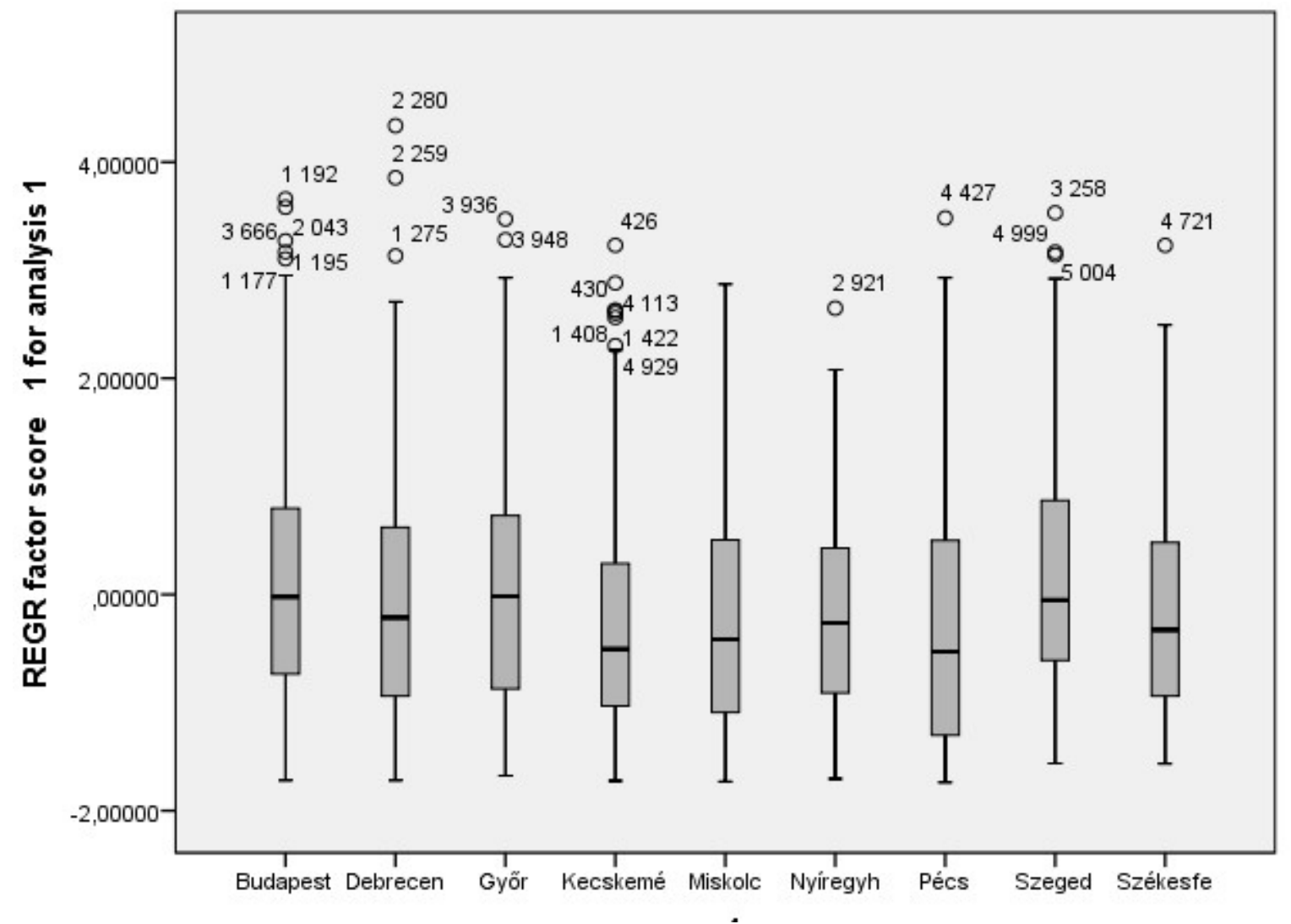

Source: own elaboration

The elaboration of four additional principal components succeeded that of the economic principal component. A „trust” factor was established in the first place. Two strong factors were revealed in the course of the analysis: one based on interpersonal, personal relationships, and another reflecting institutional trust. In view of statistical reliability, the two factors were composed of the following variables (statistical explanatory values in parantheses): 
- Personal trust composed of the following indicators: a principal component reflecting close interpersonal relationships developed on the basis of trust towards family members, friends, employers, colleagues (personal=53,78\%)

- An indicator encompassing institutional trust composed of the following variables: faith in the legal system, police, municipalities, monetary institutions, health care, educational system, state, political parties and the European Union. Both factors are characterised by an adequate explanatory value (institutional $=52.56 \%$ )

The construction of a factor expressing social activity would have been justifiable, however, its statistical unreliability might have distorted the results of the analysis.

The level of well-being of a given community in a given settlement is a non-negligible factor. This may be manifest in various forms, and increased reliability necessitated the development of a multivariate indicator as enabled by the database. Thus, the factor of „happiness" included the following variables: to what extent is the questionee cheerful, tranquil, harmonious, active, buoyant, relaxed, occupied with his or her areas of interest during the workday, success-oriented and has a competitive spirit (explanatory force: $55.22 \%)$.

The fourth and final principal component was the factor of satisfaction with the settlement. The following variables constitute the principal component: (To what extent are you satisfied with...?): the state of roads, pavements, the state of the built environment, the renovation of districts and settlement parts, the cleanliness of the settlement, health care services, entertainment facilities, the condition of the natural environment and the landscape, tranquility of the settlement, the composition of the local population. The reliability of the factor can be determined on the basis of its statistical values $(\mathrm{KMO}=0.891$; communalities above 0.5 - with two exceptions, explanatory value: $55.315 \%$ ).

\section{SOME CHARACTERISTICS OF THE FULL SAMPLE}

An analysis of the full sample $(\mathrm{N}=5022)$ was performed on the basis of the four constructed dimensions. Albeit disparities could be detected among men and women, these divergences were not significant. Men have less confidence in their environment and institutions, whereas women show higher average scores in this respect. Men seem to be slightly happier than women.

The indicators can also be examined in terms of types of workplace, which show Insignificant disparities. Public servants/officers are characterised by the highest level of trust 
towards their immediate environment, while the factor of trust towards institutions achieved high average scores just as the indicator of happiness, but in the case of individuals employed at state owned enterprises and local government owned companies, this score is surprisingly low, similarly to the case of personal trust.

Regarding individuals who are employed outside the public sphere, the disparities detected in terms of institutional trust are far more spectacular. Lower average scores characterise the dimensions of personal trust and happiness, moreover, they are also less satisfied with their settlements.

In terms of age categories, the groups between 18-29 and above 60 demonstrate lower rates of personal trust and high rates in each other category. The principal component average of institutional trust shows a positive value only above 50 years of age. The youngest age group is recognised as the happiest, average values tend to decrease with the aging process. Between $30-50$, trust is increasingly directed towards personal relations whereas it is quite low in institutional agents. Satisfaction with the settlement shows minor alterations in terms of age categories, those over 60 are feel the best in their respective settlements.

In terms of qualifications, personal trust is very low among individuals with an elementary education degree, interpersonal relationships received the highest evaluation by secondary school graduates, while trust based relationships are also significant for individuals with a tertiary education degree, however, to a considerably less extent. The intensity of trust in institutions also increases with higher qualification levels, as was demonstrated in the case of average values of principal components of happiness and satisfaction with the settlement.

Categories may also be examined on the basis of marital status. Married couples are characterised by the highest levels of trust in their immediate environment and institutions alike. Single people or bachelors are the happiest. The least satisfied, unhappiest and distrustful people are the divorced and the widows in each respect.

We have also examined the degree of trust in terms of economic activity. Personal trust is stronger in the case of individuals with an active working status than in the rest of the categories which show negative average values. Institutional confidence is the highest in case of the retired age group, followed by job holders and the unemployed who have the lowest confidence in any type of institution. Unemployed and retired people constitute the unhappiest category, the group of inactives seems to be the happiest, while the average value of the active population is also positive. Retired people love living in their settlement the most, whereas the unemployed are the least satisfied with their settlement (due to a lack of employment opportunities). 


\section{The Clusters Revealed in the Sample}

A cluster analysis relying on the four presented dimensions revealed six clusters of respondents identified in terms of their common characteristics. The following table shows the principal component average values of the thus obtained clusters:

Table 2 The mean values of principal components in the respective clusters

\begin{tabular}{|l|r|r|r|r|r|r|}
\hline & \multicolumn{7}{|c|}{ Cluster } \\
\cline { 2 - 7 } & \multicolumn{1}{|c|}{1.} & \multicolumn{1}{c|}{2.} & \multicolumn{1}{c|}{3.} & \multicolumn{1}{c|}{4.} & \multicolumn{1}{c|}{5.} & 6. \\
\hline Personal trust & -.10480 & -.70235 & 1.18511 & -.34624 & .75696 & -.77947 \\
Institutional trust & -.19783 & .53842 & -.33572 & -.71250 & .92345 & -.96731 \\
Happiness & .76055 & -.59535 & .05506 & .79538 & .85460 & -1.10055 \\
Satisfaction with the & -2.02008 & .28748 & -.24877 & .26833 & .92640 & -.75966 \\
settlement & & & & & & \\
\hline
\end{tabular}

Source: own elaboration

The characterisation of clusters:

1. Happy despite the fact that everything is bad: the level of confidence is low, does not really trust anyone, is not satisfied with his place of residence either, but is still happy.

2. Solitary institutional person: low attachment to the immediate environment and strong towards the institutional system, feels good in his place of residence, but cannot be called happy.

3. Joyful, satisfied: finds interpersonal relations important, feels trust towards his friends, colleagues and family, has less confidence in institutions, is not so satisfied with his domicile, but is nonetheless happy.

4. Solitarily happy: does not trust anyone, but loves his domicile and is also happy.

5. Uncloudedly happy: all indicators are positive, trusts his immediate environment and the institutional system alike, feels good in his place of residence, and his happiness factor is also positive.

6. Depressed, eternal pessimist: the opposite of the former group, does not trust anyone, is not satisfied with his domicile and cannot be considered happy either.

\section{Which is the city in question?}

The analyses focused on individuals' satisfaction with their place of residence. We sought to identify the location of the "settlement" where the inhabitants were feeling good. On this 
basis, we examined the proportion of the six clusters in the respective urban areas and the structures that were specific to them. The results are presented in the following table:

Table 3 The proportion of the six clusters inside the cities and their urban areas ${ }^{3}$

\begin{tabular}{|c|c|c|c|c|c|c|c|}
\hline Cities & 1 & 2 & 3 & 4 & 5 & 6 & \\
\hline \multirow{2}{*}{ Budapest } & 189 & 725 & 488 & 413 & 859 & 521 & 3195 \\
\hline & $5.9 \%$ & $22.7 \%$ & $15.3 \%$ & $12.9 \%$ & $26.9 \%$ & $16.3 \%$ & $100.0 \%$ \\
\hline \multirow{2}{*}{ Debrecen } & 8 & 72 & 77 & 50 & 24 & 75 & 306 \\
\hline & $2.6 \%$ & $23.5 \%$ & $25.2 \%$ & $16.3 \%$ & $7,8 \%$ & $24,5 \%$ & $100.0 \%$ \\
\hline \multirow{2}{*}{ Győr } & 10 & 72 & 48 & 39 & 38 & 29 & 236 \\
\hline & $4.2 \%$ & $30.5 \%$ & $20.3 \%$ & $16.5 \%$ & $16,1 \%$ & $12,3 \%$ & $100.0 \%$ \\
\hline \multirow{2}{*}{ Kecskemét } & 1. & 85 & 32 & 19 & 17 & 35 & 189 \\
\hline & $5 \%$ & $45.0 \%$ & $16.9 \%$ & $10.1 \%$ & $9.0 \%$ & $18.5 \%$ & $100.0 \%$ \\
\hline \multirow{2}{*}{ Miskolc } & 8 & 62 & 57 & 26 & 18 & 86 & 257 \\
\hline & $3.1 \%$ & $24.1 \%$ & $22.2 \%$ & $10.1 \%$ & $7.0 \%$ & $33.5 \%$ & $100.0 \%$ \\
\hline \multirow{2}{*}{ Nyíregyháza } & 66 & 21 & 19 & 22 & 16 & 20 & 164 \\
\hline & $40.2 \%$ & $12.8 \%$ & $11.6 \%$ & $13.4 \%$ & $9.8 \%$ & $12.2 \%$ & $100.0 \%$ \\
\hline \multirow{2}{*}{ Pécs } & 9 & 100 & 49 & 16 & 15 & 42 & 231 \\
\hline & $3.9 \%$ & $43.3 \%$ & $21.2 \%$ & $6.9 \%$ & $6.5 \%$ & $18.2 \%$ & $100.0 \%$ \\
\hline \multirow{2}{*}{ Szeged } & 6 & 73 & 56 & 42 & 54 & 26 & 257 \\
\hline & $2.3 \%$ & $28.4 \%$ & $21.8 \%$ & $16.3 \%$ & $21.0 \%$ & $10.1 \%$ & $100.0 \%$ \\
\hline \multirow{2}{*}{ Székesfehérvár } & 14 & 41 & 29 & 17 & 18 & 39 & 158 \\
\hline & $8.9 \%$ & $25.9 \%$ & $18.4 \%$ & $10.8 \%$ & $11.4 \%$ & $24.7 \%$ & $100.0 \%$ \\
\hline \multirow{2}{*}{$\begin{array}{ll}\text { Total } & \text { (person) } \\
(\%) & \end{array}$} & 311 & 1251 & 855 & 644 & 1059 & 873 & 4993 \\
\hline & $6.2 \%$ & $25.1 \%$ & $17.1 \%$ & $12.9 \%$ & $21.2 \%$ & $17.5 \%$ & $100.0 \%$ \\
\hline
\end{tabular}

The figures in the table indicate that the „solitary institutional person" cluster is represented in the highest proportion in the majority of cities, is characterised by a high level of institutional trust - albeit not exceeding the variance threshold -, as well as by satisfaction with the settlement.

The financial situation of clusters - especially of the above-mentioned group - is interesting to explore. A surprising, even atypical result is that albeit $41 \%$ of the group is constituted by those in the worst economic status, they still trust institutions. Presumably,

\footnotetext{
${ }^{3}$ The respondees number is low, this should be interpreted with caution
} 
having been exposed to the unfavourable consequences of the transformation of the market situation, they are expecting the amelioration of their status from public institutions.

\section{CONCLUSION}

A number of contemporary studies are concerned with the economic situation and social structure of specific settlements and the method for their quantification. However, it is crucial to examine both sides of this seemingly unilinear process. How does the population experience the disparities specific to the local society and economy? A number of researchers seek to answer this question, as is testified by the author's undertaking.

The current analysis has also unveiled some general stereotypes about better-off cities (e.g. Györ, Szeged) „as revealed by numbers” contrasting with cities with a county status in Hungary, whose inhabitants are also characterised by a higher level of satisfaction. Notwithstanding, unique phenomena and specificities whereby the local society is not necessarily aligned to the economy are also discernible. It is generally acknowledged that while the economy has a power to influence the market through its decisions and also to shape the structure of society, it can hardly influence social embeddedness. Therefore, „mobile” factors are not necessarily salvific, attention must be paid to „immobile” factors as well.

\section{REFERENCES}

Allport, G. W. (1954). The Nature of Prejudice. Addison-Wesley, Cambridge. Aronson, E. (1987). A társas lény. KJK, Budapest

Bodor, Á., Grünhut, Z. (2014). Dilemmák a területi tőke modelljének alkalmazhatóságáról: a társadalmi tőke problémája Camagni elméletében. Tér és Társadalom, 2014/3. 3-17. o.

Bourdeiu, P. (2004). Gazdasági tőke, kulturális tőke, társadalmi tőke. In Angelusz R. (ed.). A társadalmi rétegzödés komponensei. 122-137. o. Új Mandátum Könyvkiadó, Budapest.

Böhm, A. (2000). Térségi identitás Magyarországon. In Glatz F. (ed.), Területfejlesztés és közigazgatás-szervezés. Budapest, MTA. p. 111-125.

Bugovics, Z. (2007). Társadalom, identitás és területfejlesztés. L'Harmattan Kiadó, Budapest.

Giffinger, R. (2007): Territorial Capital: a new perspective on urban competitiveness? In: http://www.space.net/pdf/workshop2007/Territorial\%20Capital\%20Giffinger\%202007. pdf. (Letöltés időpontja: 2016. január 15.)

Jóna, Gy. (2013). A területi tőke fogalmi megközelítései. Tér és Társadalom, 2013/1. 30-51. 0.

Jóna, Gy. (2013). A területi tőke kistérségi jellegzetességei. Doktori (PhD) értekezés. SZIE, Gödöllö.

Lengyel, I. (2012). Regionális növekedés, fejlödés, területi tőke és versenyképesség. In Bajmóczy Z., Lengyel I., Málovics Gy. (ed.): Regionális innovációs képesség, versenyképesség és fenntarthatóság. 151-174. o. JATEPress, Szeged. 
Lin, N. (2001). Social Capital. A Theory of Social Structure and Action. Cambridge University Press, New York.

Nagy, G. D. (2011). Társadalmi kötődés és területi tőke a magyar régiókban, doktori értekezés-tervezet, PTE, BTK, Interdiszciplináris doktori iskola, Politikatudományi PhD program, Témavezető: Pálné Dr. Kovács Ilona DSc.

McGarty, C. (1999): Categorization in Social Psychology. SAGE Publications Ltd.

OECD (2001): Territorial Outlook. 15. o. Paris, OECD

Oláh, M. (2000): Adalékok a regionális identitás megrajzolásához. In Glatz F. (ed.) Területfejlesztés és közigazgatásszervezés. MTA. Budapest.

Palkó, K. (2011): Az identitás területi dimenziói a politika tükrében c. PhD-értekezés. Pécs. Témavezető: Pálné Dr. Kovács Ilona DSc.

Pálné Kovács, I. (1990): Regionalizmus a Magyar önkormányzati rendszerben Comitatus I.1. 3. p.

Pálné Kovács, I. (2000): Térszervezési stratégiák Magyarországon. In Glatz F. (ed.) Területfejlesztés és közigazgatásszervezés. MTA. Budapest.

Pataki, F. (1986): Identitás, személyiség, társadalom. Akadémiai Kiadó, Budapest

Rechnitzer, J., Grosz, A. (2005): Régiók és nagyvárosok innovációs potenciálja Magyarországon. MTA RKK.

Rechnitzer, J., Páthy, Á., Berkes, J. (2014) A magyar városhálózat stabilitása és változása. In: Tér és Társadalom, 2, pp. 105-127.

Tajfel, H. (1981): Human Groups and Social Categories. Cambridge, University Press

Tóth, B. I. (2010): Az immateriális és a területi töke összefüggései. Tér és Társadalom, 2010/1. 65-81. o. 